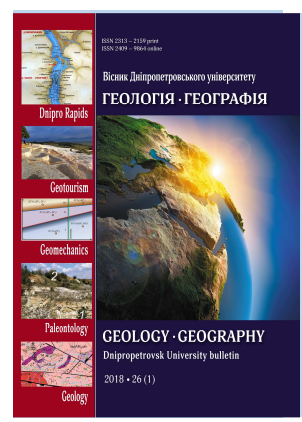

Geology $\bullet$ Geography Dnipro university bulletin

Journal home page: geology-dnu-dp.ua
ISSN 2313-2159 (print)

ISSN 2409-9864(online)

Dniprop. Univer.bulletin.

Geology, geography., 26(1), 176-183.

Dmytro S. Sopov

doi: $10.15421 / 111819$

\title{
Порушені землі Луганщини та їх класифікація
}

\author{
Д. С. Сопов \\ Уманський національний університет садівництвва, Умань, Україна, е-таil: Inau.sopov@gmail.com
}

\author{
Received 26.11.2017 \\ Received in revised form 10.01 .2018 \\ Accepted 07.02.2018
}

\begin{abstract}
Анотація.Земельні ресурси, які $є$ основним засобом виробництва, територіально обмежені. Земельний фонд Луганщини за досить нетривалий період природокористування зазнав значних змін. Екстенсивне сільськогосподарське землекористування, розроблення родовищ корисних копалин, промислове та житлове будівництво, утворення комунікацій викликало суттєву проблему -
\end{abstract} виникнення порушених земель, через що скорочуються площі, придатні для господарського використання. Порушені землі створюють реальну перспективу деградації земельного фонду, що спричинює виникнення складних економічних, екологічних, соціально-політичних проблем. Проблема дефіциту земель породила проблему рекультивації порушених земель, науково обгрунтоване вирішення якої можливе лише через удосконалення методів виявлення, обліку та класифікації таких земель. Запропоновані в різні часи класифікації порушених земель враховували або їх ознаки в сукупності, або в будь-якому поєднанні. Частіше за все ознаки, які бралися за основу класифікації, були не одного рівня, навіть несумісними. 3 метою визначення оптимальних шляхів відновлення та збереження земельного фонду розроблено класифікацію порушених земель Луганщини із зазначенням генетичного чинника, характеристикою основних видів антропогенно порушених земель, запропонованими видами рекультивації та перспективами їх відновлення та використання. Висловлена думка, що так звані порушені землі - чи то природним шляхом, чи то через господарську діяльність людини - $є$ резервом у земельному фонді області.

Ключові слова: земельний фонд, порушені землі, чинники порушення земель, сільськогосподарське виробництво, гірничо-видобувна промисловість, ерозія, класифікачія, рекультивачія.

\section{Disturbed lands of Lugansk region and their classification}

\author{
D.S. Sopov \\ Uman National University of Horticulture, Uman, Ukraine, e-mail: Inau.sopov@gmail.com
}


of land scarcity caused the problem of rehabilitation of disturbed lands, a scientifically based solution of which is possible only through the improvement of the methods of identifying, accounting and classification of such lands. Proposed at different times classification of disturbed lands were taken into account or their features in aggregate, or in any combination. Most often, the signs that were taken as a basis for the classification were not one level, even incompatible. In order to determine the optimal ways of restoration and preservation of the land fund, a classification of disturbed lands of the Luhansk region has been developed, indicating the genetic factor, the characteristics of the main types of anthropogenic disturbed lands, the proposed types of remediation and the prospects for their recovery and use. The view was expressed that so-called disturbed lands, either naturally, through the economic activity of a person, are a reserve in the land fund of the region.

Keywords: land fund, disturbed lands, factors of disturbance of land, agricultural production, mining industry, erosion, classification, reclamation.

Вступ. Постановка проблеми. Серед різних видів природокористування найбільше значення має землекористування, а земля - це головний засіб виробництва. Земельні ресурси, на відміну від інших видів природних ресурсів, мають свої ексклюзивні властивості. Серед них на особливу увагу заслуговує те, що земельні ресурси територіально обмежені і не можуть бути заміненими іншими засобами виробництва. Господарська діяльність людини впродовж досить тривалого часу докорінно змінила природне середовище. Ці зміни торкнулися в першу чергу земель. Екстенсивне сільськогосподарське землекористування, розробка родовищ корисних копалин, промислове та житлове будівництво, утворення комунікацій викликало істотну проблему - виникнення порушених земель, через що скорочуються площі, придатні для господарського використання. Порушені землі створюють реальну перспективу деградації земельного фонду, що спричинює виникнення складних економічних, екологічних, соціально-політичних проблем.

Мета статті - аналіз стану земельного фонду Луганської області.

\section{Завдання статті:}

- визначити статус порушених земель, їх види та фактори утворення;

- створити класифікацію порушених земель Луганщини;

- схарактеризувати землі, порушені промисловим і сільськогосподарським виробництвом;

- виявити можливості використання порушених земель як із господарською метою, так і для оздоровлення ландшафтів.
Аналіз попередніх досліджень. Опублікованих систематичних матеріалів стосовно Луганської області щодо досліджуваної проблеми у науковій літературі ми не виявили, тому в основній частині довелося обмежитися лише фондовими матеріалами Держгеокадастру та Державного регіонального геологорозвідувального підприємства «Схід-ДРГП».

Теоретична та регіональна (щодо України) частини базувалися на результатах досліджень вітчизняних учених та виробничників, зокрема, О. М. Адаменка, Ю. В. Буцика, О. О. Кисельової, Ю. О. Кисельова, Г. І. Рудька та ін.

Виклад основного матеріалу. Територія Луган-

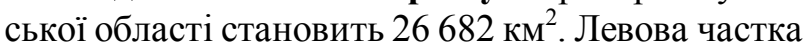
земельного фонду (74,14 \%) (рис. 1) використовується у сільськогосподарському виробництві. Міські землі займають понад 4000 км² $^{2}$ На півдні області велику площу займають гірничі виробки 3 усіма супутніми спорудами та комунікаційною мережею. Хоча сільськогосподарське, а потім і гірничопромислове виробництво на крайньому сході України розпочалося лише у XIX ст., природокористування майже відразу набрало екстенсивного характеру, що й спричинило деградацію земельного фонду через поширення порушених земель. Тобто головною причиною деградації грунтів стала господарська діяльність. Фізичне відчуження земель, ерозія грунтів, зменшення гумусового покриву, забруднення отруйними хімічними сполуками й радіонуклідами такі очевидні наслідки антропогенного впливу на землю. 

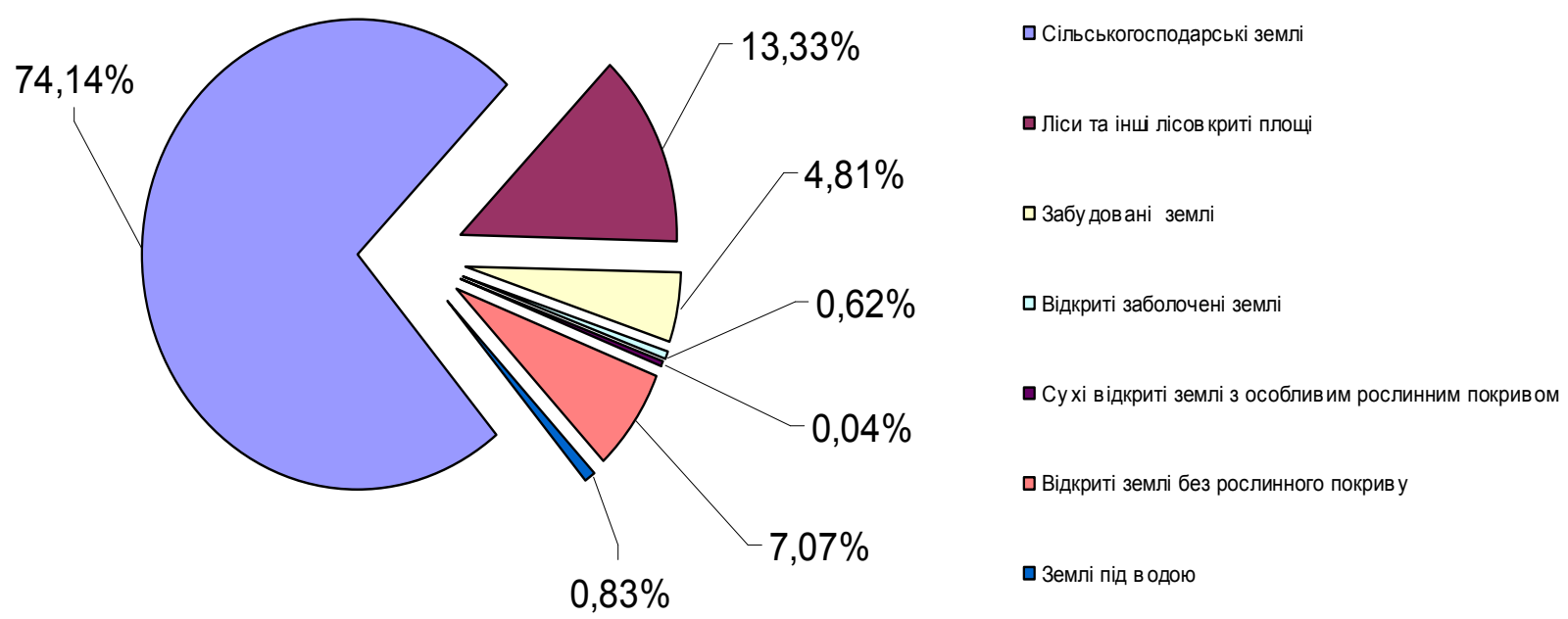

Рис. 1. Земельний фонд Луганської області на початок 2016 р.

Порушеними землями в науковій літературі та законодавчих документах вважаються такі, що втратили свої корисні властивості та родючість грунтів унаслідок впливу природних чи антропогенних факторів. Так, згідно із законом України «Про охорону земель», порушені землі - це «землі, що втратили свою господарську та екологічну цінність через порушення грунтового покриву внаслідок виробничої діяльності людини або дії природних явищ».

Крім дефініції «порушені землі», в науковій літературі зустрічається велика кількість інших: незручні, малопродуктивні, спустошені, кинуті та покинуті, забруднені, засмічені, невиробничі, післяпромислові тощо, але, незважаючи на різноманітну та строкату термінологію, всі ці землі є порушеними, хоча порушеність їх викликана різними причинами, і вони по-різному виглядають на тлі сучасних ландшафтів. Під порушеними ми розуміємо не тільки «землі, територія яких порушена у процесі геологорозвідувальних робіт, видобутку корисних копалин відкритим i підземним способом під час промислового та цивільного будівництва» (Panas, 2000), а й землі, що зазнали деградації через інтенсивну сільськогосподарську діяльність, що провокує або підсилює руйнівні ерозійні процеси.
Луганська область характеризується високим показником порушених земель, під які підпадає 3,9 \% земельного фонду. Суто за природними чинниками 14,5 \% території області не використовуються у господарстві як непридатні (засолені, заболочені та кам'янисті землі) (Derzhgeokadastr v Lugans'kij oblasti, 2016).

За відомчими матеріалами, лише сільськогосподарські угіддя на сьогодні еродовані на 66,1 $\%$, 3 них на сильнозмиті припадає 8,6 \%, середньозмиті - 15,3\%. Рілля пошкоджена водною ерозією на 66,5 \% iї площі, середньо- та сильнозмиті площі складають $14 \%$. Середньозважена величина площинної ерозії дорівнює 4 т/га/рік. Таким чином, область щорічно втрачає через площинний змив (рис. 2) близько 10 млн т грунтової маси (Kysel'ova, 2011).

На території області нараховується близько 10 тисяч ярів (рис. 3) довжиною понад 100 м і сумарною довжиною понад 3000 км. Площа ярів на території Луганщини приблизно за останні 60 років збільшилася в 12,2 раза, а за нашими підрахунками вона зростає на $1,5 \%$ за рік. Через яри виноситься 84 м³/га грунту, який відкладається нижче базису ерозії, замулюючи заплави й водоймища. Це разом із площинним змивом складає майже 13 млн т грунту (Kysel'ova, 2011). 


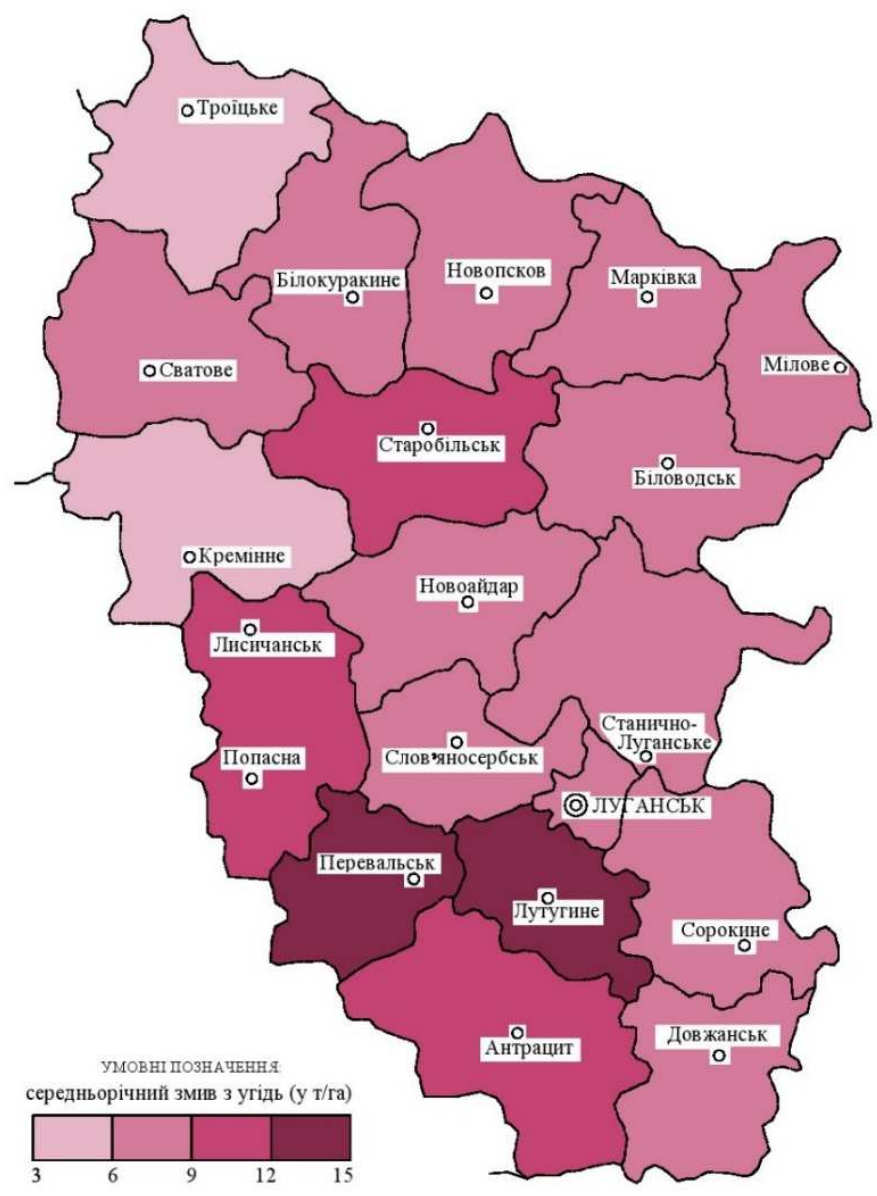

Рис. 2. Враженість території Луганської області площинним змивом (за даними Головного управління Держгеокадастру України в Луганській області, 2016 р.)

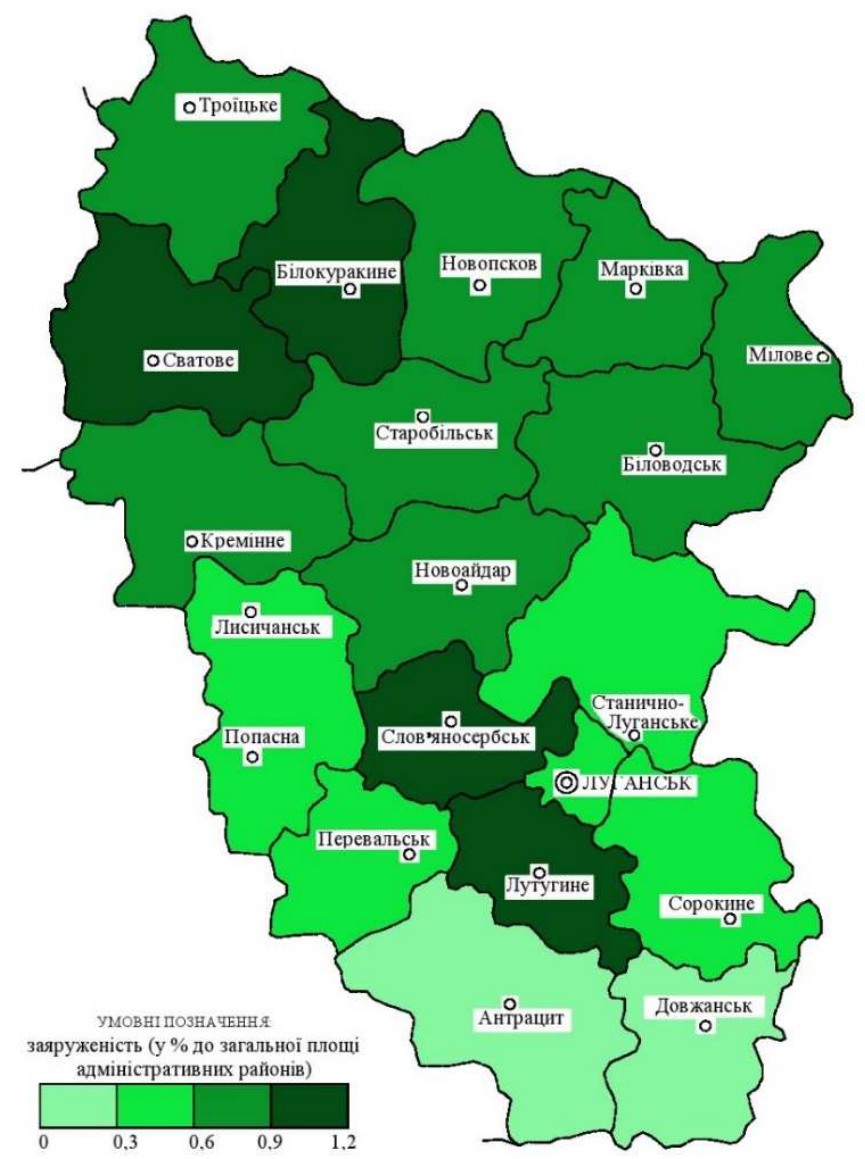

Рис. 3. Заяруженість Луганської області (у \% до загальної площі адміністративних районів) 
Поряд із втратами земель внаслідок сільськогосподарського використання, великих збитків земельному фонду завдає вугледобувна промисловість. Нагальною проблемою, пов'язаною із землекористуванням у вугільному регіоні Луганської області, бачиться скорочення земельних ресурсів унаслідок їх зайняття відвалами гірських порід і супутніми щодо шахт наземними спорудами й комунікаціями. На шахтні розробки, відвали, терикони, кар'єри припадає 17,5 \% від їх загальної площі, яка на початок 2016 року становить 11 276,85 га. Разом із площами під різного роду забудовами ця цифра сягає вже 35 \%. Достатньо згадати, що на одну умовну шахту припадає близько 1 км $^{2}$ зайнятих і порушених земель, зокрема, майже половина - під будмайданчиками. За рахунок земель, порушених підземною підробкою, цю цифру слід подвоїти (Bucik, 1993).

Велика кількість териконів (близько 50 \% від їх загальної кількості в Донбасі) займає площу 350 км $^{2}$ і ще на такій же площі вони опосередковано здійснюють негативний вплив на довкілля. У межах вугільного регіону області під час підземного видобутку вугілля шахтами

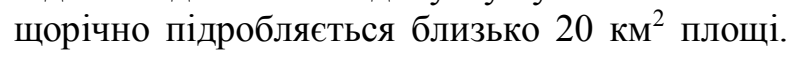
Площа порушених гірничими виробками зе- мель за весь період функціонування шахт у Луганській області становить близько 350 км² $^{2}$ що складає 1,3 \% від площі області, або 3,9 \% від площі вугільного регіону (Kysel'ov, 2000).

Ще один фактор зубожіння земельного фонду - це підтоплення: площа природного підтоплення на території області складає 68,98 км $^{2}(63 \%)$, техногенного - 25-84 км ${ }^{2}(23,6 \%)$, комплексного - 14,5 км² (13,3\%) (Derzhavne reg'ional'ne geologorozviduval'ne pidpryjemstvo «Shid-DRGP», 2014).

Та важливіше те, що в динаміці площ порушених і відпрацьованих земель у Луганській області виявляється негативна тенденція: площа порушених та відпрацьованих земель збільшується, а рекультивованих - зменшується (табл. 1).

Проблема дефіциту земель породила проблему рекультивації порушених земель, науково обгрунтоване вирішення якої можливе лише через удосконалення методів виявлення, обліку та класифікації таких земель.

Запропоновані в різні часи класифікації порушених земель враховували або їх ознаки в сукупності, або в будь-якому поєднанні. Частіше за все ознаки, які бралися за основу класифікації, були не одного рівня, навіть несумісними.

Таблиця 1. Динаміка площ порушених, відпрацьованих і рекультивованих земель

\begin{tabular}{|l|c|c|c|c|c|c|}
\hline \multicolumn{1}{|c|}{ Назва } & 2008 p. & 2009 p. & 2010 p. & 2011 p. & 2012 р. & Тенденції \\
\hline Порушені, тис. га & 10,62 & 10,656 & 10,669 & 10,666 & 10,621 & 3більшення \\
\hline \% до заг. S території & 0,39 & 0,4 & 0,39 & 0,4 & 0,398 & \\
\hline Відпрацьовані, тис. га & 4,26 & 4,299 & 4,397 & 4,407 & 4,310 & 3більшення \\
\hline \% до заг. S території & 0,15 & 0,161 & 0,16 & 0,165 & 0,161 & \\
\hline Рекультивовані, тис. га & 0,028 & 0,050 & 0,016 & 0,0339 & 0,024 & 3меншення \\
\hline \% до заг. S території & 0,001 & 0,002 & 0,0005 & 0,0001 & 0,0009 & \\
\hline
\end{tabular}

Відсутність універсальної класифікації порушених земель об'єктивно зумовлена, оскільки в різних геологічних і ландшафтних умовах чинники і наслідки порушення земель різні, тому ми у своїх розвідках розробили власну класифікацію порушених земель для свого регіону - Луганщини, в якій намагалися схарактеризувати основні антропогенно зумовлені геоморфологічні процеси та їх наслідки.

Головні порушники земель на Луганщинісільськогосподарське виробництво (головним чином землеробство) та гірничодобувна промисловість. Перший чинник спричинює розвиток ерозійних процесів, другий - докорінні геоморфолого-екологічні перетворення як верхнього шару літосфери (педосфери), так і земної повер- хні. Екстенсивне землекористування в сільському господарстві Луганської області спричинило тотальну враженість орних земель. У гірничодобувній промисловості ситуація склалася також катастрофічна. Достатньо тривалий - понад два століття - підземний видобуток кам'яного вугілля викликав і викликає створення акумулятивних і денудаційних форм техногенного рель-

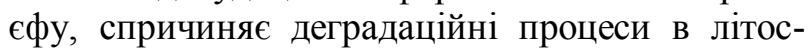
фері, особливо в педосфері, викликає порушення гідрологічного режиму поверхневих і підземних вод, знищення рослинного покриву, забруднення всіх компонентів ландшафту.

3 урахуванням наведених чинників генетична класифікація порушених земель виглядає так (табл. 2): 
Таблиця 2. Порушені землі Луганщини

\begin{tabular}{|c|c|c|c|c|}
\hline Генетичний чинник & Вид порушення & $\begin{array}{c}\text { Вираження в } \\
\text { рельєфі }\end{array}$ & Вид рекультивації & $\begin{array}{c}\text { Перспективи } \\
\text { використання } \\
\text { порушених земель }\end{array}$ \\
\hline 1 & 2 & 3 & 4 & 5 \\
\hline $\begin{array}{l}\text { Сільськогосподарське } \\
\text { виробництво }\end{array}$ & $\begin{array}{l}\text { Площинна ерозія, } \\
\text { лінійна ерозія; } \\
\text { зниження родючості, } \\
\text { забруднення земель }\end{array}$ & $\begin{array}{l}\text { Яри, промивини, } \\
\text { водориї, змиті } \\
\text { землі }\end{array}$ & $\begin{array}{l}\text { Сільськогосподарська } \\
\text { рекультивація, } \\
\text { задерніння, залісення } \\
\text { схилів }\end{array}$ & $\begin{array}{l}\text { Утворення штучних } \\
\text { водоймищ, утворення } \\
\text { рекреаційних зон }\end{array}$ \\
\hline Гірнича промисловість & $\begin{array}{l}\text { Утворення } \\
\text { акумулятивних } \\
\text { форм рельєфу, } \\
\text { фізичне відчуження } \\
\text { земель. } \\
\text { Заболочення, } \\
\text { просідання. } \\
\text { Забруднення } \\
\text { компонентів } \\
\text { ландшафту. } \\
\text { Скидання засолених } \\
\text { шахтних вод у } \\
\text { гідрографічну } \\
\text { мережу, засолення і } \\
\text { деградація грунтів }\end{array}$ & $\begin{array}{l}\text { Терикони, } \\
\text { відвали, } \\
\text { хвостосховища, } \\
\text { кар'єри, } \\
\text { депресійні лійки, } \\
\text { локально- } \\
\text { катострофічні } \\
\text { суксесії } \\
\text { рослинності }\end{array}$ & $\begin{array}{l}\text { Рекультивація } \\
\text { териконів та відвалів, } \\
\text { озеленіння, } \\
\text { використання } \\
\text { «порожньої породи» } \\
\text { для дорожнього } \\
\text { будівництва тощо }\end{array}$ & $\begin{array}{l}\text { Формування «зелених } \\
\text { зон», використання } \\
\text { матеріалу для } \\
\text { заповнення шахтних } \\
\text { виробок, використання } \\
\text { породи як } \\
\text { будівельного } \\
\text { матеріалу, зокрема в } \\
\text { дорожньому } \\
\text { будівництві; вторинне } \\
\text { збагачення }\end{array}$ \\
\hline $\begin{array}{l}\text { Переробна } \\
\text { промисловість }\end{array}$ & $\begin{array}{l}\text { Утворення звалищ } \\
\text { відходів, фізичне } \\
\text { відчуження земель, } \\
\text { забруднення } \\
\text { довкілля }\end{array}$ & $\begin{array}{l}\text { Звалища, } \\
\text { хвостосховища }\end{array}$ & Озеленіння & $\begin{array}{l}\text { Переробка сміття, } \\
\text { створення } \\
\text { будмайданчиків }\end{array}$ \\
\hline Транспорт & $\begin{array}{l}\text { Перепланування } \\
\text { рельєфу, фізичне } \\
\text { відчуження земель, } \\
\text { забруднення } \\
\text { довкілля } \\
\end{array}$ & $\begin{array}{l}\text { Дорожні виїмки, } \\
\text { насипи }\end{array}$ & $\begin{array}{l}\text { Укріплення відкосів, } \\
\text { утворення } \\
\text { оптимальних зелених } \\
\text { захисних смуг }\end{array}$ & \\
\hline $\begin{array}{l}\text { Будівництво (житлове і } \\
\text { промислове) }\end{array}$ & $\begin{array}{l}\text { Фізичне відчуження } \\
\text { земель, забруднення, } \\
\text { утворення звалищ }\end{array}$ & $\begin{array}{l}\text { Сміттєвалища, } \\
\text { перепланування } \\
\text { рельєфу }\end{array}$ & $\begin{array}{l}\text { Очищення } \\
\text { забруднених та } \\
\text { засмічених ділянок, } \\
\text { залісення }\end{array}$ & $\begin{array}{l}\text { Будівництво, } \\
\text { створення } \\
\text { рекреаційних зон }\end{array}$ \\
\hline Селитебні землі & $\begin{array}{l}\text { Утворення } \\
\text { сміттєзвалищ, } \\
\text { забруднення } \\
\text { довкілля, } \\
\text { рекреаційне } \\
\text { навантаження } \\
\end{array}$ & $\begin{array}{l}\text { Сміттєзвалища, } \\
\text { перепланування } \\
\text { рельєфу }\end{array}$ & & \\
\hline Кинуті землі & $\begin{array}{l}\text { Мікроформи і } \\
\text { мезоформи рельєфу, } \\
\text { утворені внаслідок } \\
\text { воєнних дій, кинуті } \\
\text { аеродроми, } \\
\text { залізничні колії, } \\
\text { заміновані території, } \\
\text { інші комунікації. }\end{array}$ & $\begin{array}{l}\text { Фізичне } \\
\text { відчуження } \\
\text { земель, } \\
\text { засмічення, } \\
\text { забруднення. }\end{array}$ & $\begin{array}{l}\text { Очищення територій, } \\
\text { дезактивація. } \\
\text { Залісення, створення } \\
\text { рекреаційних зон. }\end{array}$ & $\begin{array}{l}\text { Повернення у } \\
\text { господарське } \\
\text { використання. }\end{array}$ \\
\hline
\end{tabular}

Порушення земель відбувається не лише через прискорену (антропогенну) ерозію та деформацію літосфери. Небезпеку становить проблема забруднення грунтів викидними газами автомобільного транспорту. Небезпечне засмічення і забруднення земель промисловими, побутовими, сільськогосподарськими та іншими відходами.

Значного екологічного збитку навколишньому середовищу завдають так звані несанкці- оновані звалища міських відходів. Незадовільний стан у Луганській області стався з організацією знешкодження та захоронення відходів на полігонах (рис. 4). Кількість сміттєзвалищ в області лише за офіційними даними сягає 57 , а щодо площі інформація відсутня. Кількість полігонів дорівнює 29, їх площа становить близько 210 га. Заводів із переробки твердих побутових відходів на Луганщині немає. 


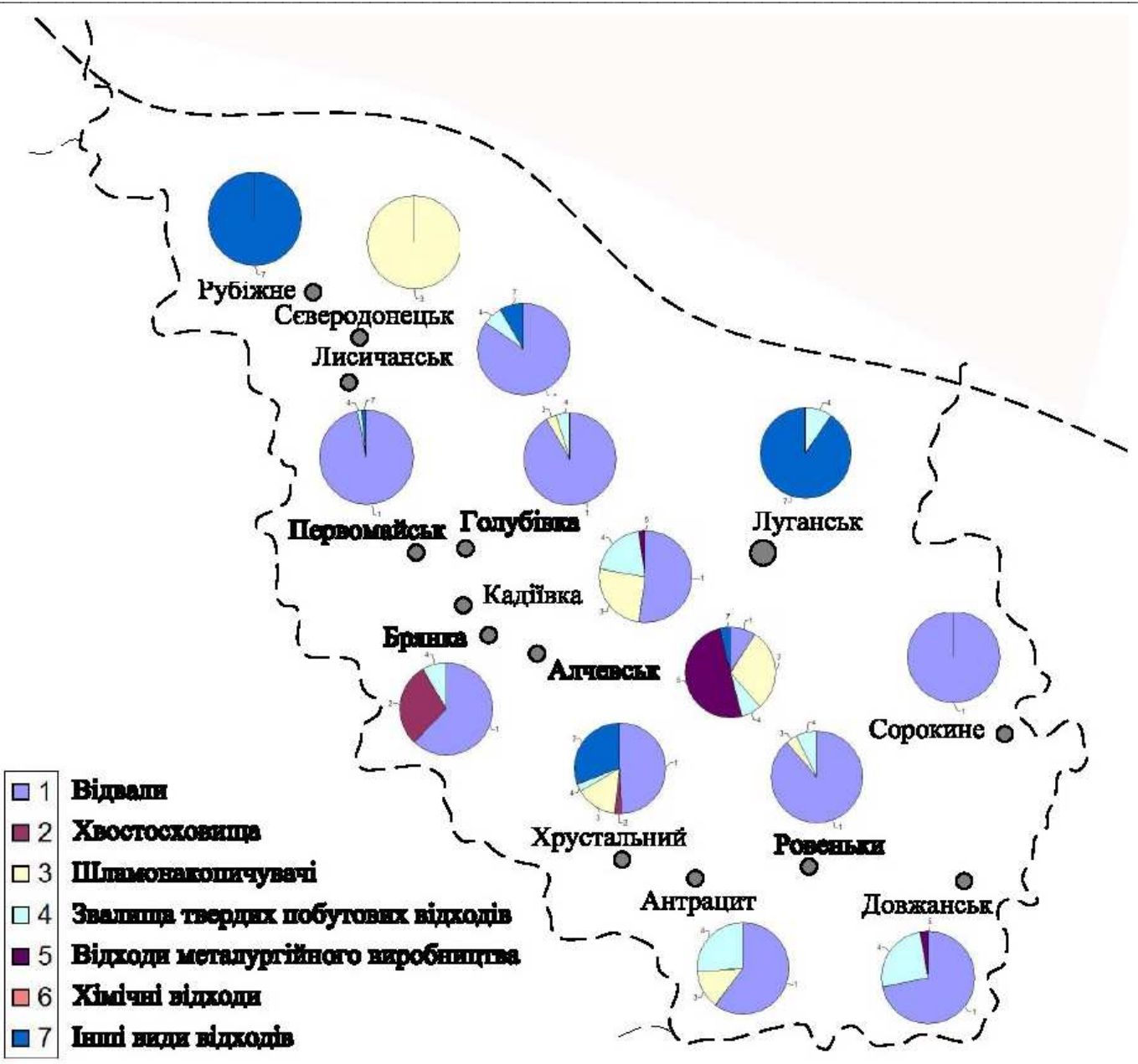

Рис. 4. Поширення відходів у промислових містах Луганської області (станом на 01.01.2013 р.)

За Г. І. Рудьком і О. М. Адаменком, «ефективною територією вважається територія, що придатна для господарського освоєння» (Rud'ko, 2009). Для Луганщини ефективною можна вважати всю територію області, незважаючи на офіційно визнані майже 4 \% непридатних для господарського використання земель. Граничною площею економічно вигідних для експлуатації земель $є$ вся територія області, що цілком слушно для Луганщини.

Ми виходимо $з$ того, що навіть такі землі, які зайняті відходами виробництва, кам'янисті та піщані, заболочені та еродовані, можуть бути потенційно освоєні після певного типу рекультиваціï. Весь доступний фонд орних земель в області вичерпано, і на Луганщині утворилася парадоксальна ситуація: активна деградація земель викликає зменшення придатних до сільськогосподарського використання земель і збільшення резервних земель. Такого парадоксу можна уникнути єдиним шляхом: не розширювати площу оброблюваних земель, а змінювати характер їх використання, тобто змінити екстенсивний шлях розвитку продуктивних сил регіону на інтенсивний.
Цілком слушне твердження О. Г. Топчієва, що «група малопродуктивних і деградованих сільськогосподарських земель після їх додаткових обстежень та інформаційно-картографічних зіставлень і накладень потребує значних корегувань щодо дійсних площ та реального розподілу на місцевості» (Topchijev, 2012), потрібна лише зміна структури землекористування, підвищення врожайності на існуючих екологічно придатних орних землях, оптимальна хімізація та іригація, дотримання вимог до використання техніки, виведення і використання високоврожайних сортів сільськогосподарських культур та високопродуктивних порід у тваринництві. Таким чином, ми вважаємо, що так звані порушені землі - це резерв земельного фонду області.

Порушені з певних причин землі потребують відповідних заходів. Розроблена нами класифікація з подальшими рекомендаціями фахівціввиробничників має послугувати визначенню оптимальних шляхів їх реабілітації та раціонального використання. Так, в умовах жорсткого водного дефіциту в області доцільним бачиться використання негативних форм рельєфу для створення мальовничих водойм; створення лісових 
насаджень на непридатних для сільськогосподарського використання землях послугувало б розвиткові рекреаційно-туристичної галузі тощо. Це сприяло б вирішенню і екологічних, і економічних, і соціальних проблем. Спорудження підприємств із переробки відходів і сміття, що є однією з найболючіших проблем Луганщини, сприяло б розв'язанню економічних, екологічних, естетичних, соціальних проблем.

Ще попереду оцінювання наслідків окупації південних районів області та бойових дій у їх межах, розв'язаних гібридними російсько-сепаратистськими збройними формуваннями, що тривають уже понад три роки. Звісно, земельний фонд цього регіону постраждав докорінно, як i взагалі природне довкілля. Рекультивація порушених земель у цьому регіоні має два цілком реальні аспекти: екологічний і естетичний, врахування яких дозволить уже в найближчому майбутньому вирішити й інші, не менш актуальні, проблеми функціонального використання земель. Головною ж метою рекультивації порушених земель ми вважаємо збереження земельного фонду та формування різноманітних та екологічно збалансованих ландшафтів.

Висновки. Усі види порушених земель, на наше переконання, становлять резерв у структурі земельного фонду, яким не можна нехтувати. Оскільки непорушених земель зараз просто не існує (рекультивовані - це теж порушені свого часу землі, які наразі можуть перебувати у стадії реміciï), то всі землі ми вважаємо такими, що потребують суцільного бонітування, рекультивації, ретельного догляду та раціональних підходів до використання.

Порушені території після комплексу відбудовних робіт мають використовуватися для створення зон зелених насаджень загального й обмеженого користування, спеціального призначення; промислових зон і зон зовнішнього транспорту; житлових районів і мікрорайонів; рекреаційних зон; зон водних регулювальних устроїв; рибогосподарських і сільськогосподарських зон; зон водопостачання; комунально-складських зон тощо.

\section{Бібліографічні посилання}

Bucik, Ju.V. 1993. Soobshhenie materialov po tehnogennomu vozdejstviju ugol'nyh shaht na geologojekologicheskuju obstanovku v Ukrainskoj chasti Donbassa [Communication of materials on the technogenic impact of coal mines on the geological and ecological situation in the Ukrainian part of Donbass]. Kyiv, 1 - 299 (in Russian).

Kysel'ov, Ju.O. 2000. Vydy pryrodokorystuvannja v Lugans'kij oblasti ta i'h ekologo-geomorfologichni naslidky [Types of nature use in the Luhansk region and their ecological and geomorphological consequences]. Science at the turn of the century. Materials of the scientific conference. Lugansk, 95-98 (in Ukrainian).

Kysel'ova, O.O. 2011. Ekologichna ocinka erozijnoi' vrazhenosti zemel' Luganshhyny cherez ploshhynnyj zmyv [Environmental assessment of erosion of landscapes of Lugansk region through flat wash]. Social, Physical-Geographic and Geo-Ecological Problems of Old-Industrial Districts: Materials of the All-Ukrainian Scientific and Practical Conference devoted to the 75th anniversary of the formation of the Department of Geography at the Lugansk National Taras Shevchenko University, 157-160 (in Ukrainian).

Panas, R.M. 2000. Racional'ne vykorystannja ta ohorona zemel' [Rational use and protection of land]. Textbook - Lviv, New World, 1 - 352 (in Ukrainian).

Rud'ko, G.I. 2009. Zemlelogija / Ekologo-resursna bezpeka Zemli [Ecology / Ecological and resource safety of the Earth]. Kyiv, Academpospr., 1 - 512 (in Ukrainian).

Topchijev, O. G. 2012. Zastosuvannja metodiv analizu velykomasshtabnyh planiv zemlekorystuvan' pry ormuvanni reg'ional'nyh ekomerezh [Application of methods of analysis of largescale land use plans in the formation of regional eco-networks]. Ukrainian Geographic Magazine, 3, p. 51-57 (in Ukrainian).

Fondovi materialy Golovnogo upravlinnja Derzhgeokadastru V Lugans'kij oblasti. 2016. [Stock Materials of the Main Department of the State Service for Geodesy, Cartography and Cadastre of Ukraine in the Lugansk region]. (in Ukrainian).

Fondovi materialy Derzhavnogo reg'ional'nogo geologorozviduval'nogo pidpryjemstva «ShidDRGP» 2014. [Stock Materials of the State Regional Exploration Enterprise "East-DRHP"]. (in Ukrainian). 